(Vol.VI, Maret 2015 )

\title{
PENGARUH PERAN PENDAMPINGAN SUAMI TERHADAP PERCEPATAN PROSES PERSALINAN KALA I FASE AKTIF DI BPS KISWORO SURABAYA
}

\author{
Sumiati \\ Tenaga Pengajar Prodi. D-III Kebidanan Universitas PGRI Adi Buana Surabaya
}

\begin{abstract}
ABSTRAK
Rasa nyeri selama persalinan kala I fase aktif menimbulkan rasa takut yang akan menimbulkan ketegangan vegetative pada otot-otot polos yang manifestasinya berupa kekakuan mulut rahim sehingga menghambat pembukaan cervix uteri. Penelitian ini bertujuan untuk mengetahui hubungan pendampingan suami terhadap percepatan proses persalinan kala I fase aktif di BPS Kisworo Surabaya.

Desain penelitian menggunakan "Guesi exsperimental", pengambilan sampel dilakukan secara purposive sampling. Populasi penelitian adalah semua ibu bersalin. di BPS Kisworo Surabaya pada bulan September 2014 sampai Januari 2015 sejumlah 72 orang. Sampel penelitian adalah sebagian ibu bersalin sejumlah 30 orang yang terbagi 15 orang didampingi suami dan 15 orang tidak didampingi suami. Instrumen pengumpulan data menggunakan kuesioner dan lembar partograf.

Analisa data menggunakan uji statistik independent sample t-test untuk mengetahui pengaruh pendampingan suami terhadap percepatan kala I fase aktif dilakukan tabulasi silang dan analisanya menggunakan uji chi-square dengan tingkat kemaknaan $\alpha \leq 0,05$.

Berdasarkan hasil penelitian didapatkan bahwa percepatan kala I fase aktif pada kelompok perlakuan dan kelompok kontrol, responden yang didampingi suami mengalami percepatan kala I fase aktif rata-rata 4,53 jam, sebaliknya responden yang tidak didampingi suami memerlukan waktu fase aktif rata-rata 7 jam. Selisih waktu dari 2 kelompok adalah : 2,47 jam.

Hasil analisa chi-square tentang pengaruh pendampingan suami terhadap percepatan kala I fase aktif menunjukkan bahwa 11 responden dengan peran pendampingan baik, semua mengalami percepatan, sedang 4 responden dengan peran pendampingan kurang baik hanya 1 responden yang mengalami fase aktif yang cepat.

Hasil analisa chi-square tentang pengaruh peran pendampingan suami terhadap percepatan kala I fase aktif didapatkan hasil : $x^{2}$ hitung $>x^{2}$ tabel, disimpulkan bahwa terdapat pengaruh yang signifikan peran pendampingan suami terhadap percepatan kala I fase aktif..
\end{abstract}

Saran peneliti diharapkan bidan dapat memfasilitasi pentingnya peran pendampingan suami selama proses persalinan.

Kata kunci : Peran pendampingan suami, percepatan proses persalinan.

\section{PENDAHULUAN}

Persalinan adalah proses pengeluaran hasil konsepsi (janin \& uri) yang telah cukup bulan atau dapat hidup diluar kandungan melalui jalan lahir atau jalan lain dengan bantuan atau tanpa bantuan yaitu dengan kekuatan sendiri (Ida Gde Bagus
Manuaba, 2010) yang perlu mendapatkan perhatian keperawatan karena bila tidak ditangani dengan baik merupakan kondisi yang dapat mengancam jiwa baik pada ibu dan anak yang akan dilahirkan. Menurut laporan Depkes RI (2001), banyak ibu hamil di Indonesia yang tidak mau 
meminta pertolongan tenaga penolong persalinan terlatih untuk memberikan perawatan selama mereka dalam proses persalinan. Sebagian dari alasan mereka karena penolong persalinan yang sudah terlatih tersebut tidak benar-benar memperhatikan kebutuhan mereka atau menghormati kebiasaan, tradisi maupun kebutuhan pribadi mengenai bagaimana mereka saat persalinan dan kelahiran bayinya. Alasan lain yang juga berperan adalah kenyataan bahwa sebagian fasilitas persalinan mempunyai peraturan dan prosedur yang amat asing dan menakutkan bagi para ibu dengan tidak memperkenalkan ibu untuk berjalan-jalan selama proses persalinan, tidak mengijinkan anggota keluarga untuk mendampingi ibu dan membatasi keinginan-keinginan yang lain. Peraturan dan kebiasaankebiasaan ini merupakan salah satu faktor yang mempengaruhi lambatnya proses persalinan terutama pada persalinan fase kala I. Oleh sebab itu kajian tentang pengaruh pendampingan suami terhadap percepatan proses persalinan kala I menjadi sangat dibutuhkan.

Angka Kematian Ibu (AKI) di Indonesia merupakan angka tertinggi di Negara-negara ASEAN lainnya. Menurut SDKI (2004), AKI masih 230/100.000 kelahiran hidup, diantara penyebab kematian ibu di Indonesia antara lain disebabkan oleh perdarahan sebanyak $42 \%$, eklampsi $13 \%$, aborsi $11 \%$, infeksi $10 \%$, partus lama 9\%, dan lain-lain 15\% (Susena dan Modul Kependudukan AKI, 2000). Sekalipun angka kematian ibu Indonesia mengalami penurunan, tetapi penurunan ini masih jauh dari kesepakatan Millenium Development Goals (MDG's) pada tahun 2015 dimana AKI menjadi 115/100.000 kelahiran hidup. Upaya atau strategi yang dapat dilakukan oleh bidan di masyarakat untuk menekan angka kematian ibu adalah dengan memberikan perhatian dan perlakuan khusus pada ibu hamil, bersalin, nifas dan bayi baru lahir (Asrinah, 2010). Melihát data di atas memberikan gambaran bahwa angka kematian ibu akibat proses persalinan sangat dominan. Padahal angka ini bisa diturunkan dengan cara memberikan pelayanan persalinan yang bermutu. Pelayanan bermutu berarti memberikan bantuan sepenuhnya kepada klien untuk tercukupinya kebutuhan dasar, termasuk kebutuhan rasa aman dan nyaman selama proses persalinan. Dengan demikian kajian mengenai pengaruh pendampingan terhadap percepatan persalinan kala I masih dianggap penting. Di dalam proses persalinan semua wanita akan mengalami nyeri, meskipun reaksi yang terjadi pada setiap individu berbeda-beda. Nyeri adalah rangsangan tidak menyenangkan yang dapat menimbulkan rasa kekhawatiran dan biasanya karena tidak tahu akan proses yang terjadi, dan menyebabkan orang merasa takut dan cemas (Mander, 2012). Faktor lain proses persalinan merupakan beban bagi ibu. Hal ini merupakan stressor. Stressor ini akan direspon tubuh berupa respon stress. Kecemasan pada ibu bersalin dapat juga merupakan stessor. Kecemasan ini disebabkan oleh faktorfaktor psikososial seperti : kurangnya perhatian dari petugas kesehatan serta tidak adanya orang terdekat yaitu suami atau keluarga yang ikut dalam proses persalinan uintuk memberikan dukungan moral (Sarwono, 2006). Adanya perasaan cemas atau stress pada ibu inpartu mempengaruhi peningkatan sekresi adrenalin yang dampaknya terhadap ibu : terjadi penurunan kontraksi uterus sehingga menyebabkan persalinan lama. Efekefek yang dapat ditimbulkan pada ibu yaitu : terdapat kenaikan insiden atonia uteri, laserisasi, pendarahan, infeksi, kelelahan ibu dan shock. Sedangkan bagi janin akan meningkatkan morbiditas dan mortalitas karena terjadinya asphyxia, tauma cerecri, 
cidera akibat tindakan ekstraksi dengan forceps serta dapat terjadi infeksi sistemik.

Memperhatikan kondisi diatas upaya yang dapat dilakukan dalam menciptakan persalinan yang cepat dan aman yaitu dengan memberikan asuhan persalinan berfokus pada pengawasan kemajuan persalinan, memantau kondisi ibu dan janin selama dalam persalinan. Dukungan keluarga dan orang terdekat lainnya diharapkan dapat memberikan rasa tenang dan aman selama proses persalinan berlangsung. (Depkes RI, 2001). Menurut (Matterson,2011) pendampingan suami selama hospitalisasi dapat meningkatkan support sosial. Walaupun peran psikologis belum jelas dalam proses persalinan, tetapi dinyatakan bahwa dukungan fisik dan emosional selama proses persalinan dapat menyebabkan persalinan yang lebih singkat, mengurangi angka komplikasi dan atau tindakan obstetrik, meningkatkan kepercayaan diri dan kepuasan. Konsep yang ditawarkan diatas lebih memusatkan pada pengaruh pendampingan suami terhadap percepatan proses persalinan kala I fase aktif.

\section{Rumusan Masalah}

Dari latar belakang yang telah di uraikan di atas dapat ditarik suatu rumusan maslah sbb :

1. Apakah peran pendampingan suami dapat mempengaruhi percepatan proses persalinan kala I fase aktif?

2. Apakah ada perbedaaan dalam percepatan proses persalinan kala I fase aktif bagi ibu inpartu yang didampingi suami dan yang tidak didampingi suami?

\section{METODE PENELITIAN}

\subsection{Desain Penelitian}

Berdasarkan tujuan penelitian, desain penelitian yang digunakan adalah "Quesi experimental" dimana dalam pengukuran variabel responden diberikan intervensi secara khusus yaitu dengan pendampingan suami, kemudian dilakukan observasi pengaruhnya terhadap lama persalinan kala I fase aktif dengan mencatat data pembukaan cerviks menggunakan partograf dari WHO. Sebagai pembanding diberi juga kelompok kontrol tanpa perlakuan.

Rancangan penelitian :

Pada penelitian ini berdasarkan desain yang dipilih menggunakan rancangan penelitian " non randomized control goup post test design"

( M. Zainuddin, 2000)



Keterangan:

$\mathrm{P} \quad$ = populasi

$\mathrm{X}=$ kelompok perlakuan

$\mathrm{Y}=$ kelompok kontrol

Q I = percepatan kala I fase aktif setelah perlakuan

Q 2 = percepatan kala I fase aktif tanpa perlakuan

\subsection{Tempat dan Waktu Penelitian}

Tempat penelitian dilakukan di BPS. Kisworo Pratiwi JI. Kemlaten VIII / 22 Surabaya.

Waktu penelitian dilakukan pada bulan September 2014 sampai dengan Januari 2015. 
1.3Kerangka penelitian

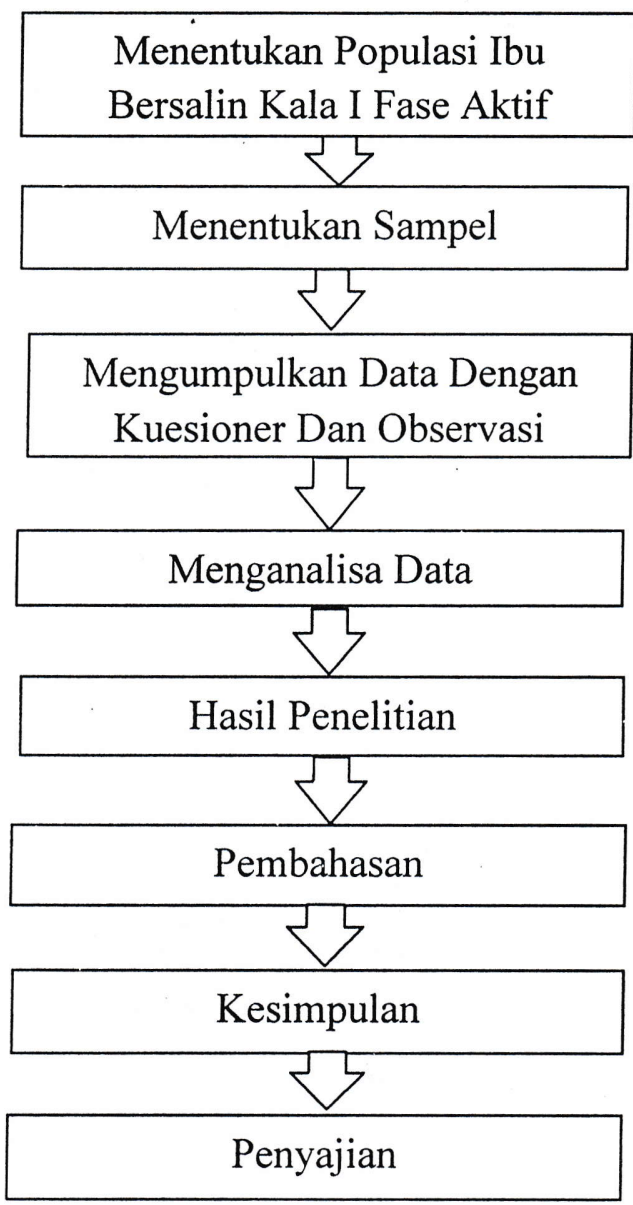

1.4Populasi, Sampel dan Besar Sampel

Populasi

Populasi pada penelitian ini adalah semua ibu bersalin dalam keadaan inpartu kala I yang fisiologis di BPS Kisworo Surabaya. Jumlah populasi sebanyak 72 orang.

Sampel

Teknik sampling berupa Purposive Sampling dimana sampel yang memenuhi criteria inklusi. Kriteria inklusi dalam penelitian ini adalah :

(I) Pasien inpartu dengan kehamilan primigravida

(2) Berumur 17 -35 tahun

(3) Tidak disertai penyakit lain

(4) Tidak mendapat obat-obatan

(5) Bersedia untuk diteliti

Besar sampel pada

penelitian ini adalah 30

responden, yang dibagi menjadi
15 responden adalah kelompok perlakuan, dan 15 responden sebagai kelompok kontrol.

\subsection{Instrument Penelitian}

Alat yang digunakan untuk mengetahui percepatan persalinan kala I fase aktif adalah menggunakan lembar partograf $\mathrm{WHO}$, dan lembar observasi terhadap penilaian peran suami membantu memenuhi kebutuhan pasien (kebutuhan makan minum, toileting, beraktivitas, memberi motivasi, menemani, mengajak bicara), membantu proses persalinan.

\subsection{Pengumpulan Data dan Analisis Data}

Data dikumpulkan melalui observasi pada responden yaitu ibu dalam proses persalinan kala I fase aktif yang memenuhi kriteria inklusi.

Setelah semua data dari responden terkumpul untuk mengetahui perbedaan percepatan persalinan kala I fase aktif pada kedua kelompok yaitu yang didampingi suami dan yang tidak didampingi suami, menggunakan analisa parametrik dengan uji statistik independent sample t-test. Untuk mengetahui pengaruh peran pendampingan suami terhadap percepatan kala I fase aktif dilakukan tabulasi silang dan analisanya menggunakan uji Chi-Square. Untuk masing-masing data menggunakan tingkat kemaknaan $\alpha \leq 0,05$.

\subsection{Pengolahan an analisis data}

\subsubsection{Editing}

Data yang didapatkan akan diperiksa, kemudian dikumpulkan terlebih dahulu 
dan diteliti ulang sebelum di olah lebih lanjut

\subsubsection{Codding}

Memberikan kode pada responden yaitu :

Angka 1, pada responden yang di damping suami

Angka 0 , pada responden yang tidak di damping suami

\subsubsection{Skoring}

Memberikan skor pada masing-masing responden tentang peran pendampingan suami terhadap percepatan proses persalinan kala I fase aktif dengan cara :

Skor 2 : dengan peran pendampingan baik

Skor 1 : dengan peran pendampingan kurang baik

\subsubsection{Tabulating}

Memasukkan data dalam tabel tentang distribusi frekuensi hasil pengeluaran percepatan kala I antara kelompok dengan pendampingan suami dan kelompok tanpa pendampingan suami.

1.7.5 Teknik pengolahan dan analisis data :

Untuk mengetahui percepatan kala I fase aktif kelompok perlakuan dan kelompok kontrol, dimasukkan tabel distribusi frekuensi hasil pengukuran percepatan kala I, selanjutnya akan dhitung : mean, percepatan minimum dan maksimum, standart deviasi dan standart error. Sedangkan untuk mengukur pengaruh peran pendampingan suami terhadap kecepatan kala I fase aktif menggunakan uji stastistik chi-square dengan kemaknaan $\alpha \leq 0,05$.
1.7.6 Alat ukur yang digunakan

Menggunakan lembar partograf WHO untuk mengukur percepatan proses persalinan kala I fase aktif dan lembar kuesioner untuk mengukur peran pendampingan terhadap suami persalinan kala I fase aktif.

\section{HASIL PENELITIAN}

Pada bab ini akan disajikan seluruh hasil penelitian sesuai rumusan masalah dalam penelitian.

\subsection{Data Umum}

Meliputi karakteristik responden yang terdiri dari :

\subsubsection{Umur}

Grafik 2.1.1 : jumlah responden menurut kelompok umur

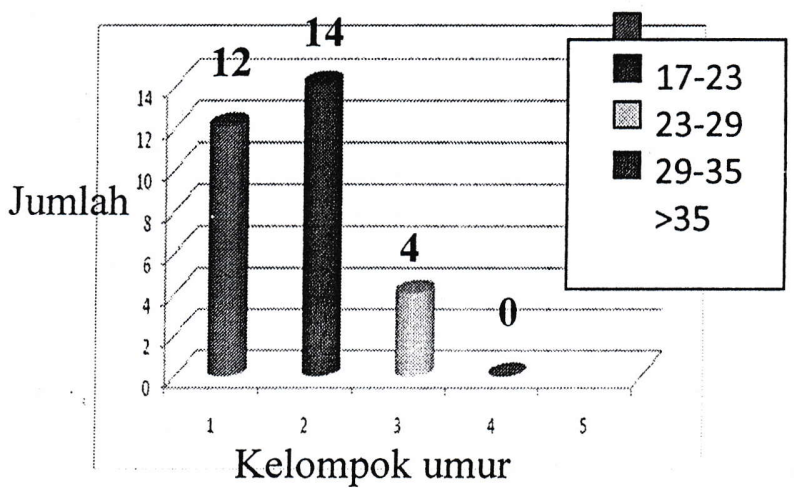

Dari grafik 2.1.1 didapatkan gambaran bahwa jumlah responden sebagian besar berada pada kelompok umur 23-28 tahun, $(46,7 \%)$, kelompok umur 17-23 tahun (40\%), kelompok 29-34 tahun $(13.3 \%)$, sedang kelompok umur $>35$ tahun tidak ada. 


\subsubsection{Pendidikan}

Grafik 2.1.2 : Jumlah responden menurut tingkat pendidikan

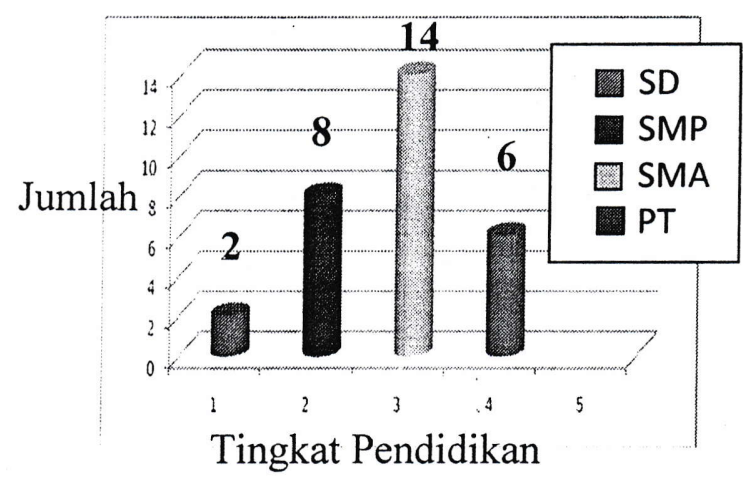

Dari grafik 2.1.2 didapatkan gambaran bahwa tingkat pendidikan responden SD $(6,6 \%)$, SMP $(26,7 \%)$, SMA $(46,7 \%)$ dan PT $(20 \%)$

\subsubsection{Pekerjaan istri}

Grafik 2.1.3 : Jumlah responden menurut jenis pekerjaan

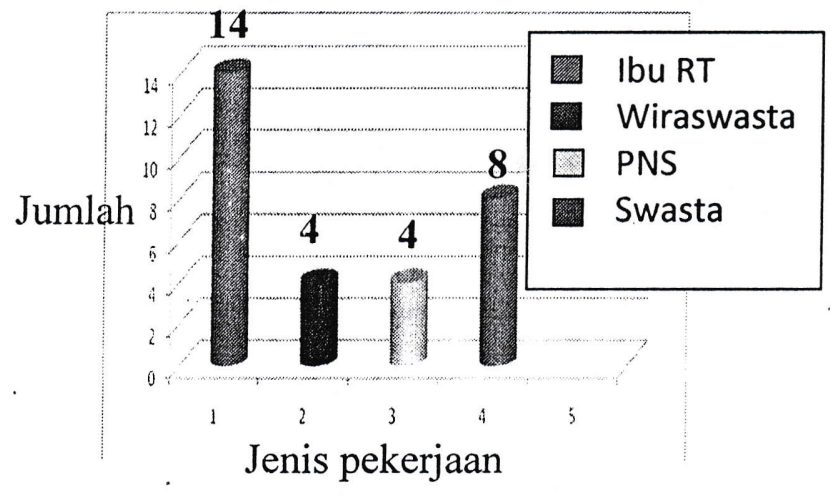

Dari grafik 2.1.3 didapatkan gambaran bahwa tingkat pekerjaan responden sebagian besar ibu rumah tangga $(46,7 \%)$, selebihnya wiraswasta $(13,3 \%)$, PNS $(13,3 \%)$ dan pegawai swasta $(26,7 \%)$

\subsubsection{Pekerjaan suami}

Grafik 2.1.4 : Jumlah responden menurut pekerjaan suami

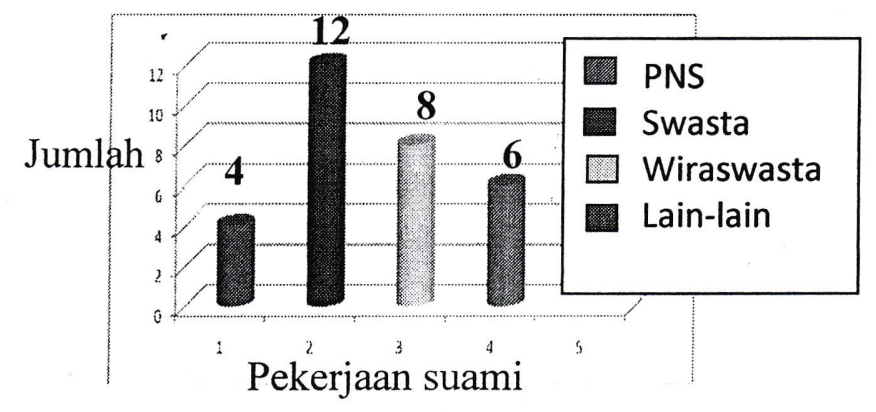

Dari grafik 2.1.4 didapatkan gambaran tingkat pekerjaan suami sebagian besar pegawai swasta (40\%), selebihnya PNS (13,3\%), wiraswasta $(26,7 \%)$, dan lain-lain $(20 \%)$

2.1.5 Pendamping

$$
\begin{aligned}
& \text { Grafik 2.1.5 : jumlah } \\
& \text { responden menurut } \\
& \text { pendamping }
\end{aligned}
$$

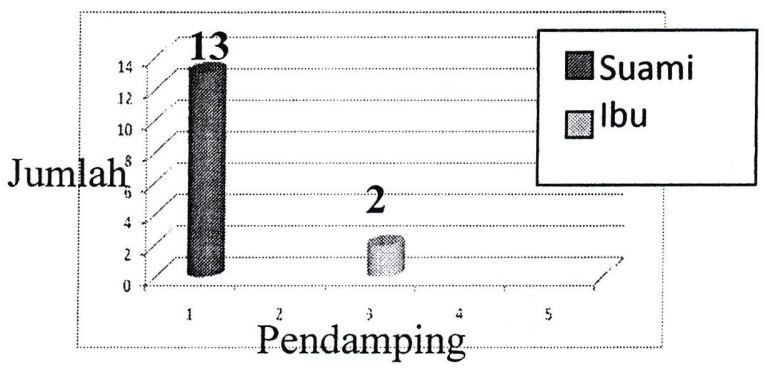

Dari grafik 2.1 .5 didapatkan gambaran bahwa pendamping mayoritas adalah suami $(86,7 \%)$ dan selebihnya ibu responden $(13,3 \%)$.

\subsection{Hasil pengukuran pengaruh peran pendampingan}

Hasil pengukuran percepatan kala I fase aktif dilakukan satu kali yaitu setelah perlakuan.

2.2.1 Hasil pengukùran percepatan kala I fase aktif seluruh responden.

Tabel 2.2.1 Distribusi frekuensi hasil pengukuran percepatan kala I antara kelompok perlakuan dan kelompok control 
Dari tabel

2.2.2

\begin{tabular}{|c|c|c|c|}
\hline Responden & \multicolumn{3}{|c|}{ Percepatan kala I fase aktif } \\
\cline { 2 - 4 } & $\begin{array}{c}\text { Kelompok } \\
\text { perlakuan }\end{array}$ & $\begin{array}{c}\text { Kelom } \\
\text { pok } \\
\text { kontrol }\end{array}$ & $\begin{array}{c}\text { Total } \\
\text { respon } \\
\text { den }\end{array}$ \\
\hline 1 & 3 & 7 & \\
2 & 7 & 9 & \\
3 & 6 & 10 & \\
4 & 4 & 6 & \\
5 & 5 & 8 & \\
6 & 5 & 6 & \\
7 & 4 & 7 & \\
8 & 6 & 7 & \\
9 & 4 & 7 & \\
10 & 5 & 5 & \\
11 & 4 & 6 & \\
12 & 3 & 7 & \\
13 & 5 & 7 &. \\
14 & 5 & 7 & \\
15 & 3 & 6 & \\
\hline Mean & 4,53 & 7,00 & 5,77 \\
Minimum & 3 & 5 & 3 \\
Maximum & 7 & 10 & 10 \\
Std. Deviation & 1,17 & 1,25 & 1,73 \\
Std. Error & 0,30 & 0,32 & 0,32 \\
N & 15 & 15 & 30 \\
\hline
\end{tabular}

Ket : fase aktif cepat $=<\cdot 6$ jam, fase aktif lambat $>6$ jam

Tabel diatas menunjukkan hasil percepatan kala I fase aktif pada kelompok perlakuan dan kelompok kontrol. Responden yang didampingi suami mengalami percepatan kala I fase aktif rata-rata 4,53 jam, sebaliknya bagi responden yang tidak didampingi suami memerlukan waktu pada fase aktif rata-rata 7 jam.

2.2.2 Hasil analisa perbedaan percepatan kala I fase aktif antara kelompok perlakuan dan kelompok control

Tabel 2.2.2 Hasil analisa independent sample t-test percepatan kala I fase aktif tiaptiap kelompok setelah perlakuan

\begin{tabular}{|c|c|c|c|c|c|c|}
\hline Kelompok & $\mathrm{N}$ & Mean & $\mathrm{SD}$ & $\mathrm{df}$ & $\mathrm{t}$ & $\mathrm{p}$ \\
\hline Perlakuan & 15 & 4,53 & 1,17 & \multirow{2}{*}{28} & 5,567 & 0,000 \\
\hline Kontrol & 15 & 7,00 & 1,25 & & & \\
\hline
\end{tabular}

menunjukkan hasil bahwa terdapat perbedaan yang signifikan terhadap percepatan kala I fase aktif antara kelompok perlakuan dan kelompok kontrol dengan nilai kemaknaan $p=0,000$; perbedaan waktu dari kedua kelompok tersebut adalah 2,47 jam

2.2.3 Hasil analisa chi-square pengaruh peran pendampingan keluarga terhadap percepatan kala I fase aktif pada kelompok perlakuan

Tabel 2.2.3 Hasil analisa chisquare pengaruh peran pendampingan terhadap percepatan kala I fase aktif

\begin{tabular}{|c|c|c|c|}
\hline \multirow{3}{*}{ Peran } & \multicolumn{2}{|c|}{$\begin{array}{c}\text { Percepatan } \\
\text { kala I fase aktif }\end{array}$} & \multirow{2}{*}{ Total } \\
\cline { 2 - 3 } & Lambat & Cepat & \\
\hline \multirow{3}{*}{ Kurang } & 3 & 1 & 4 \\
& 0,8 & 3,2 & 4,0 \\
& $20 \%$ & $6,7 \%$ & $26,7 \%$ \\
\hline \multirow{3}{*}{ Baik } & 0 & 11 & 11 \\
& 2,2 & 8,8 & 11,0 \\
& $0 \%$ & $73,3 \%$ & $73,3 \%$ \\
\hline \multirow{3}{*}{ Total } & 3 & 12 & 15 \\
& 3,0 & 12,0 & 15,0 \\
& $20 \%$ & $80 \%$ & $100 \%$ \\
\hline \multirow{2}{*}{ Hasil } & \multicolumn{3}{|c|}{$X^{2}=10,31$ df $=1 \mathrm{p}=0,009$} \\
& \multicolumn{3}{|c|}{ Uji Fisher's Exact test } \\
\hline
\end{tabular}

Ket : Peran suami dalam pendampingan : sebagai pelatih, bagian tim dan saksi dlm persalinan

Dari tabel 2.2.3 diatas menunjukkan bahwa dari 11 responden dengan peran pendampingan yang baik, semua mengalami percepatan kala I fase aktif, sedangkan dari 4 responden dengan peran keluarga dalam pendampingan yang kurang baik hanya 1 responden yang mengalami fase aktif yang cepat. $\mathrm{Hal}$ ini menunjukkan hasil analisa bahwa ada pengaruh yang signifikan antara peran pendampingan 
keluarga terhadap percepatan kala I fase aktif dengan nilai kemaknaan $p=0,009$

\section{PEMBAHASAN}

3.1Pengaruh peran pendampingan terhadap percepatan kala I fase aktif.

Setelah dilakukan analisa data dan melihat hasil yang telah diperoleh, pada bagian ini akan dibahas sejauh mana peran pendampingan suami berpengaruh terhadap proses percepatan persalinan kala I fase aktif.

Peran pendampingan suami dalam proses persalinan ternyata mempunyai pengaruh yang signifikan terhadap percepatan kala I fase aktif dengan nilai kemaknaan $p=0,009$ yang berarti percepatan kala I fase aktif sangat dipengaruhi oleh ada tidaknya pendampingan. Selama pendampingan, suami berperan sebagai pelatih yaitu membantu dan menolong ibu secara aktif selama dan setelah kontraksi uterus, memberikan dorongan pada ibu untuk istirahat antar kontraksi dan mengingatkan tentang teknik bernapas. Disamping itu, suami juga berperan sebagai tim medis/paramedis yang dapat merespon keinginan-keinginan ibu secara fisik dan emosional, memberikan perhatian, sentuhan dan dukungan serta sebagai saksi dalam proses persalinan. Kehadiran suami didekat ibu diharapkan menjadi teman yang dapat memberikan dukungan emosional dan moral. Dengan demikian, ibu merasa aman dan nyaman, rasa takut dan kekhawatirannya berkurang, sehingga dapat mengubah perilaku maladaptive menjadi perilaku dan koping yang baru yang konstruktif (Budi Anna
Keliat, 1996). Apabila rasa ketakutan dapat dikurangi maka ketegangan vegetative akan menurun sehingga mencegah terjadinya kekakuan otot-otot mulut rahim. Ototo-otot mulut rahim menjadi lunak, mudah menipis dan membuka (Lowdermilk, 2004). Kemampuan mulut rahim yang mudah menipis dan membuka akan mempercepat proses persalinan kala I fase aktif.

Keluhan utama responden selain rasa nyeri, juga perasaan takut menghadapi persalinan. Pengaruh nyeri yang menakutkan juga dapat menginduksi pengeluaran hormon adrenalin yang dapat menyebabkan vasokonstriksi sehingga suplai $\mathrm{O} 2$ dalam uterus berkurang. Otototot uterus akan menjadi hipoksia, yang mengakibatkan kontraksi uterus menurun atau lemah sehingga persalinan kala I fase aktif menjadi lebih lama. Dengan menurunnya perasaan nyeri yang menakutkan dapat mencegah pengeluaran hormone adrenalin yang berlebihan, sehingga peredaran darah menjadi lancar, suplai $\mathrm{O} 2$ kedalam otot-otot uterus terpenuhi, kontraksi uterus menjadi lebih baik dan kuat, sehingga proses pembukaan serviks dapat berjalan lebih cepat.

\subsection{Perbedaan percepatan kala fase aktif diantara 2 kelompok}

Dari uji pengolahan data menunjukkan hasil bahwa terdapat perbedaan yang signifikan terhadap percepatan kala I fase aktif antara kelompok perlakuan dan kelompok kontrol dengan nilai kemaknaan $\mathrm{p}=$ 0,000 . Bila dilihat secara deskriptif memberikan gambaran bahwa percepatan kala I fase 
aktif pada kelompok perlakuan lebih baik disbanding kelompok kontrol. Rata-rata percepatan kedua kelompok terdapat perbedaan waktu yang signifikan yaitu 4,53 jam dengan 7 jam yang berarti terdapat percepatan waktu 2,47 jam.

Pada kelompok kontrol, dimana persalinan kala I fase aktif tanpa peran pendampingan suami, menunjukkan hasil ratarata percepatan kala I fase aktif 7 jam. Percepatan kala I paling tinggi adalah 5 jam dan paling lambat 10 jam. Artinya bahwa bila tanpa peran pendampingan percepatan kala I fase aktif akan menunjukkan kelambatan 1-4 jam dikaitkan dengan pembukaan normal fase aktif yang membutuhkan waktu 6 jam. Faktor pengaruh pada kelompok ini antara lain : 1) Pada ibu inpartu mengalami stress berkepanjangan, 2) lbu inpartu kurang mampu mengendalikan mekanisme koping yang dimiliki, 3) Adanya kecemasan dan ketakutan tanpa adanya fase relaksasi. Keadaan ini dapat dipacu oleh ketatnya peraturan dan prosedur bahwa suami tidak diperbolehkan menunggu istrinya saat proses persalinan.

Bagaimana pengaruh
peran pendampingan mampu
memberikan efek stimulasi
terhadap proses pembukaan
serviks pada persalinan kala I fase aktif. Menurut Putra ST (1996), peran itu ada hubungannya antara system saraf pusat dan imun. Menurut kajian psikoneuroimunologi hubungan itu melalui system endokrin dibawah pengendalian hipotalamo - pituitary - adrenal axis. Komunikasi ini dimulai dari sinyal adanya perasaan nyaman dan aman yang dimiliki oleh ibu karena peran pendampingan, sinyal ini akan diteruskan ke otak sebagai stimulus. Stimulus ini bersifat stimulator bukan stressor. Sampai di otak diproses oleh korteks serebri, kemudian ke hipotalamus melalui system limbik. Neurotransmitter yang dihasilkan dikirim kekelenjar hipofisis sehingga kelenjar ini tidak mengeksresi hormone kortikosteroid. Karena hormone ini ditekan maka peningkatan adrenalin juga bisa ditekan sehingga neurotransmitter prostaglandin mampu merangsang kontraksi uterus efeknya pembukaan serviks menjadi cepat. Bila stimulator berubah menjadi stressor maka kelenjar hipofisis akan mengeluarkan hormone kortikosteroid. Hormon ini memiliki penekanan sistem imun dan meningkatkan neurotransmitter supresor sehingga stress akan berkepanjangan (Putra ST, 1996).

Untuk mengatasi efek yang merugikan pada saat persalinan yaitu terjadinya persalinan lama, maka perlu perbaikan mekanisme coping. Upaya yang bisa dilakukan adalah adanya peran pendampingan suami. Tidak ada metode coping yang paling baik dan tidak ada satupun yang dapat diterapkan pada segala jenis stress. Karenanya pemilihan kapan waktu yang tepat penerapan pendampingan ini membutuhkan strategi dan skill sehingga tepat sasaran, waktu, tempat, dosis dan situasi. Berdasarkan hasil penelitian waktu yang tepat adalah kala I fase aktif. 


\section{KESIMPULAN}

Berdasarkan penelitian diatas maka dapat dirumuskan kesimpulan sebagai berikut :

1. Ada pengaruh yang signifikan antara peran pendampingan suami terhadap percepatan kala I fase aktif dengan nilai kemaknaan $p=0,009$ karena dengan adanya suami disamping ibu saat inpartu dapat memberikan rasa nyaman dan aman, kecemasan menurun, dengan demikian ibu mampu mengalahkan stressor berupa persalinan dengan mekanisme pengelolaan nyeri yang baik dengan bantuan peran pendampingan keluarga tersebut.

2. Terdapat perbedaan yang signifikan terhadap percepatan kala I fase aktif antara kelompok perlakuan dan kelompok kontrol dengan nilai kemaknaan $p=$ 0,000 . Percepatan kala I fase aktif pada kelompok perlakuan lebih baik disbanding kelompok kontrol. Rata-rata percepatan kedua kelompok terdapat beda yang signifikan yaitu 4,53 dibanding 7,00 yang berarti terdapat percepatan waktu 2,47 jam.

\section{Saran}

1. Berdasarkan hasil penelitian diatas, untuk meningkatkan mutu pelayanan khususnya bagi ibu bersalin sebaiknya setiap rumah sakit atau klinik bersalin mengijinkan suami untuk mendampingi ibu inpartu dalam proses persalinan kala I fase aktif.

2. Bidan dalam memberikan intervensi pada saat ibu mengalami inpartu kala I fase aktif hendaknya mengijinkan suami untuk mendampingi ibu, dimana sebelum peran pendampingan ini diberlakukan sebaiknya diberikan arahanarahan tentang fungsi dan peran pendampingan, yang sudah dimulai sejak ibu dalam masa pranatal. Pengarahan tersebut dapat diberikan secara kelompok ataupun secara individu dengan memberikan leaflet yang terkait dengan peran keluarga saat pendampingan.

3. Perlu dilakukan penelitian lebih lanjut tentang peran yang paling dominan dapat berdampak terhadap percepatan persalinan kala I fase aktif dengan sampel yang lebih besar dan representatif.

\section{DAFTAR PUSTAKA}

Ari Sulistyawati, Esti Nugrahaeni (2010), Asuhan Kebidanan Pada Ibu Bersalin, Salemba Medika, Jakarta

Asrinah, 2010, Asuhan

Kebidanan Pada Masa

Persalinan, Yogyakarta : Graha IImu

Budi Anna Keliat (1996), Hubungan Terapeutik Perawat klien, EGC Jakarta.

Dep. Kes. RI (2001), Asuhan Persalinan Normal, Jakarta.

Ida Bagus Gde Manuaba, (2010), Ilmu Kebidanan Penyakit Kandungan dan Keluarga Berencana, EGC, Jakarta.

JNPR-KR, (2010), Asuhan Persalinan Normal, JNPK$\mathrm{KR}$, Jakarta.

Hamilton, Persis Mary (1995), Dasar-dasar Keperawatan Maternitas, edisi Indonesia, Penerbit EGC, Jakarta. 
(Vol.VI, Maret 2015 )

Lowdermilk, Perry, Bobak, (2004), Maternity Nursing, Mosby, St. Louis.

Mander, R (2012), Nyeri

Persalinan, EGC, Jakarta.

Muhamad Zainuddin, (2000),

Metodologi Penelitian, Jakarta.

Nursalam (2001), Pendekatan

Praktis Metodologi Riset

Keperawatan, CV. Sagung Seto, Jakarta.

Noto Atmojo, Sukidjo (2010), Metodologi Penelitian Kesehatan, Rineka Cipta, Jakarta.
Putra St. Setyawan (1996),

Pengaruh Latihan

Terhadap Variabel

Ketahanan Tubuh, Suatu

Pendekatan

Psikoneuroimmunologi,

Surabaya

Sarwono Prawiroharjo, 2006, IImu Kebidanan, Jakarta : Bina Pustaka Sarwono Prawiroharjo

Yudha, dkk (2012), Teori

Pengukuran Nyeri \& Nyeri Persalinan, EGC, Yogyakarta

M. Zainudin, (2000), Metodologi

Penelitian , EGC.

Jakarta 